\title{
Entry into the Postparental Phase of the Family Life Cycle
}

\section{Barbara Wawrzyniak}

\begin{abstract}
The article examines entry into the postparental phase of the family life cycle, which is the familial situation when all children have moved out of the parental household. We position this event chronologically within the life course and examine the probability of occurrence. Using panel data ( 3 survey waves) covering a period of 40 years of a cohort of former North-Rhine Westphalian grammar school pupils, event history models (Cox regression) are employed to analyse what factors accelerate or decelerate the transition. This revealed that the parent's individual biography (in particular the age at the own move out, age at the birth of the first child and the number of children) has a major impact on the time of occurrence, while the occupational history has no effect. In addition, sons delay the transition, while children's academic studies and occupation accelerate it.
\end{abstract}

Keywords: Postparental family phase - Move out of the last child - Empty nest · Panel study $\cdot$ Cox regression

\section{The postparental phase of the family life cycle}

When children become adults and leave their parental home, a new phase begins in the lives of parents: the postparental phase. Only in the $20^{\text {th }}$ century did this phase of life develop to a period lasting many years constituting 25 to 35 percent of people's entire lifespan (Lauterbach 2004: 229). The lengthening of this phase implies that relationships between adult children and their parents must be shaped for a longer period than those between minor children and their parents, since the time for childcare takes up only one fourth of our entire lifetime (Nave-Herz 2002: 57). Entry into the postparental phase is less institutionalised than marriage or the birth of a child (Scherger 2007).

For parents, this period of life holds new challenges for consolidating the relationships between the couple and the children. Rearing of the children is no longer the focus; everyday family life changes. Earlier studies report of the so-called empty-nest syndrome, accompanied by depression and other mental ailments of 
mothers (e.g. Bart 1971; Deykin et al. 1966). Later research, by contrast, refutes the emergence of these problems (e.g. Radloff 1980) and refers to rather ambivalent emotions among mothers (Feser et al. 1989). Papastefanou (2000) even reports positive assessments of spatial separation between family members. Geographical distance brings about a reduction in the daily friction between parents and children and the experience of living alone with all its challenges leads young adults to be more understanding of their parents (Papastefanou 2000: 62).

The moving out of one's children can be assessed both positively and negatively depending on the kind of relationship to the children and whether the move is considered as a step towards desired independence or rather as an early "escape" from the parental home. In addition, departure affects both the parenthood as well as the intimate relationship: "... on the one hand the lack of daily contact with the children is missed sadly; on the other it is clearly recognized that both the individual as well as the relationship development profit from it" (Papastefanou 2000: 58, translated by CPoS). However, a strong fixation on the parental role impairs coping with the transition into the postparental phase (Papastefanou 2000: 58). In particular for those mothers who gave up their jobs for the family, the move of their children is a difficult situation: "Since mothers lose one of their most meaningful tasks, they often have the feeling they are no longer needed, combined with depression, mourning and identity crisis" (Pinquart/Silbereisen 2007: 498, translated by CPoS). Yet there are studies that also show that this phase can be accompanied by positive experiences for women, identified as a reduction in negative and a rise in positive emotions among mothers whose children have left home. An increase in general well-being and decrease in minor everyday annoyances is also ascertained (Dennerstein et al. 2002). By contrast, fathers appear to have few problems with the move of their children, though those who are highly dedicated to their work may feel regret that they missed out on watching their children grow up. And difficulties can also occur among fathers in unhappy relationships in which the children occasionally acted as an integrative factor (Papastefanou 1997).

The quality of the relationship between adult children and their parents during this phase is characterised by low geographical distance and a great closeness, whereby mothers and daughters are the closest. As for drifting apart, we see nothing of the sort (Szydlik/Schupp 1998: 311), however parents assess their relationship with their own children as closer than the children perceive it and also tend to emphasize the intergenerational similarities and play down conflicts, while the children underemphasize similarities and overemphasize conflicts (Szydlik/Schupp 1998: 304).

This article focuses on the transition into the postparental phase, which is marked by the move of the last child. It explains how the transition can be positioned chronologically within the life course of parents and on which factors the entry into the postparental family phase depends. It incorporates both the individual and occupational biographies of the parents as well as the children into the multivariate analyses. First, we will portray the current state of research on the transition into the postparental phase and on the leaving behaviour of young adults. Based on previous results, we aim to identify possible influencing factors in order to include 
them into the analyses. Then, we describe the sample, methodologies and data basis employed here before presenting the descriptive and multivariate results.

\section{Determinants influencing entry into the postparental phase}

Only a few studies (Lauterbach 2004; Mayer/Wagner 1989) have focused on the perspectives and the situation of parents when their own children or of the last child leave(s) home, which is why this aspect will now be analysed further. By contrast, the leaving behaviour of young adults has been examined extensively in a number of studies. Berger (2009) offers an overview of the current state of research on leaving behaviour and its determining factors. In summary, the time when men and women leave home differs (Berger 2009; Ziegler/Schaldt 1993; Mayer/Wagner 1989; Scherger 2009). Women leave the parental home earlier than men, depending on the study on average by two to five years and usually in their early twenties. Berger (2009) identifies an age difference ranging between 21.2 years among women and 22.8 years among men (median), while Ziegler and Schladt (1993) ascertain an even narrower difference and identify an earlier age upon leaving home: 20.6 years among women and 21.9 years among men (median).

In addition, there are distinct correlations between the vocational and individual biography and the leaving behaviour of young adults (Ziegler/Schladt 1993; Mayer) Wagner 1989), whereby home-leaving behaviour in Germany faced structural transitions in recent decades. While earlier, leaving was highly linked to marriage (Mayer/Wagner 1989), today it is more linked with new types of living arrangements such as non-marital cohabitation (Berger 2009). Today, vocational training and entry into the labour market prove to be chronologically more closely related to the leaving behaviour than they were earlier (Berger 2009: 198).

In their analysis of the home-leaving behaviour of the cohort of the Kölner Gymnasiastenpane/ (Cologne grammar school pupil panel, abbreviated KGP), Ziegler and Schladt (1993) conclude that the process of detachment from the parental home is not dependent on social origin, but rather on events and turning points in their institutionally controlled ${ }^{1}$ life course, hence transitions within the educational system, entries into working life and (marital or non-marital) relationships. Berger (2009), too, demonstrated that working and the respective economic independence very distinctly accelerates the move out of the parental home among women and men. Beginning to study also leads to a higher probability of leaving home among both genders. The influences of vocational training, by contrast, are not as strong; it did not significantly increase the tendency to leave home. The educational level does play a role in the sense that remaining longer within the school system leads to a later departure and this delays economic independence. Entering into a relationship is also an important factor determining the probability of leaving home. This rises distinctly when young adults enter a lasting, non-marital relationship (Berger 2009: 232).

1 These are events that are institutionalised by tradition or are rather institutions themselves (such as marriage). 
Living standard also plays an important role in the decision to move out of the parental home. If it is high and likely to deteriorate distinctly following departure, the prospects of a worsening of one's living situation has a rather inhibitory effect on the decision to move out (Wagner 1989: 173). The parents' financial resources can have two opposite effects on the decision to move out: a financially well-endowed household can lead to a high housing comfort for the children and thus delay departure, or a high parental household income can provide more support for the child's own household, thus leading to an earlier departure (Wagner 1989: 174). The familial constellation, measured by the number of children, can also be a factor in the time of departure. A large number of children could assumedly imply that the older siblings could satisfy their need for privacy by moving out, while an only child would remain at home longer (Lauterbach 2004: 163). Family structure is another important factor, which is not, however, taken into consideration in the following analyses. Stepchildren and the children of single parents tend to move out earlier than children who live together with both of their biological parents (Mitche/l 1994). The influence of stepfamilies and single parents was excluded here due to limitations in the data with regard to the family history.

These influences on the leaving behaviour of young adults are important factors determining the entry into the postparental family phase; however those that characterise the lives of the parents also need to be identified. An early beginning of the postparental phase can result from a variety of influences: early marriage age, early age at the birth of the first child, small number of children and less time between births (Mayer/Wagner 1989: 29). But what about the parents' educational histories? What influence does it have on the chronological position of the entry into the postparental phase? Parents with academic degrees may want their children to receive an adequate education and can also financially ensure this (Meulemann 1995). Parents having academic degrees can influence the time of departure of the children in two opposing ways: if the children take up studies close to home, the departure is delayed, if they study elsewhere, it is accelerated. In her comparison of a number of cohorts, Scherger (2007) comes to the conclusion that the postparental phase begins a few years later among men and women with a university entrance diploma (Abitur), which indicates that children of more highly educated parents go through longer educational processes that delay leaving home (Scherger 2007: 186). In this context, Wagner (1989) determines that the educational level of the parents has an opposite effect if the type of household of the children following departure is also examined. When the children marry on departure, then a higher parental educational level delays the departure. When they do not marry, the educational level accelerates the departure (Wagner 1989: 182).

Having a working mother accelerates the leaving behaviour of children. On the one hand, a working mother can serve as a role model for greater independence - in particular for daughters - and on the other hand, it may also lead to earlier detachment due to less pronounced overprotection of the children (Ziegler/Schladt 1993).

This article aims to identify central factors affecting the entry into the postparental phase based on previous research findings. The focus is not only put on analyses of individual spheres of the lives of parents, but on panel analyses of both the influ- 
ence of the individual as well as the occupational history as well as the characteristics of the children.

\section{Sample, methodology and data}

\subsection{Sample}

The analyses are conducted using the data from the KGP, which includes a birth cohort from 1953 until 1956. The respondents were first surveyed via a PAPI (paper and pencil) interview in 1969 when they were still pupils in the tenth form at NorthRhine Westphalian grammar schools. Of the then 3,240 participants, 1,987 people could be won for a face-to-face follow-up survey in 1984/85. A second follow-up survey was conducted in 1997 with 1,596 people by telephone and finally, a third survey wave was held, also by phone, in 2010 with 1,301 participants. The questionnaire includes a biographical section, which covers the schooling, training, university, occupational, family and relationship biographies. In addition, there are a series of attitude and leisure time questions and, in the latest survey, questions about preparations for old age. In each survey wave an additional thematic focus was chosen, for example, the first follow-up survey focussed on the process of identity formation of the young people between the ages of 16 and 30 , while the second follow-up survey concentrated on the maintenance of identity of the adults between the ages of 30 and 43 . The third wave deals with the further development of identity and preparations for old age. It is particularly advantageous that the entire relationship and family histories from the age of 16 until 56 is recorded for the 1,301 respondents who took part in the third survey wave in 2010.Therefore we can create a precise overview of the duration and course of relationships for this cohort as well as information about vocational training, schooling, income and vocation of the partner. Information about the schooling, vocational training and academic studies of their children is also available as well as the date that they left home, frequency of contact and questions about grandchildren. It must be noted, however, that this sample is a highly selective subpopulation regarding education, whose selectivity has increased somewhat over the course of 40 years (Birkelbach 2011: 27).

Not all respondents were included in the following analyses, but only those who were still married at the age of 56 years, have children, and are not separated, divorced or widowed. They are therefore people who have lived through the normal course of the family life cycle (Glick 1955; Höhn 1982) and whose family histories are marked by the same events, namely: marriage, birth and the leaving of the children. The exclusion of people with critical events in their family histories (Filipp 1990 ) is meant to prevent these events from having an effect on the entry into the postparental phase and to primarily identify the influences of biographical characteristics of the parents and children. The influence of critical events on the entry into the postparental phase would have to be examined in a separate study. After all, 605 of the 1,301 respondents, or 47 percent of the sample, fulfil these criteria. For these 605 respondents, we checked the time that the last child moved out of the parental 
household. The precise question was, "In what year did your child have his/her own household for the first time; I mean his/her own home?", (translated by CPoS). This did not necessarily have to refer to the youngest child.

\subsection{Methodology}

In order to be able to position the transition into the postparental phase within the life course, we estimated a transition rate using the life table method. The transition rate corresponds to the risk of changing the present status, for example from single to married (Diekmann/Mitter 1984). The transition rate $h_{j k}(t)$ indicates the probability that an event will occur in a specific time interval $t$, under the condition that it has not yet occurred by the beginning of this interval, and can be described as follows (Blossfeld 2010: 1001):

$$
h_{j k}(t)=P(T=t \mid T \geq t) t=1,2,3 \ldots
$$

The durations are divided into monthly intervals and in each interval we count the number of cases that are still at risk of experiencing the event at the beginning of the interval as well as the number of cases who experienced an event and those that have to be censored in an interval (Blossfeld 2010: 1003; translated by CPoS). This results in the probability that no event will occur prior to a specific time, in this case that the transition into the postparental phase does not take place. The cumulative percentage of survivors at the end of the interval is used for the graphic illustration of the survival rate and we can therefore see at what age what share of respondents is exposed to the risk of the transition.

Then a Cox regression (Cox 1972; Blossfeld et al. 2007; Blossfeld 2010) is used to check what factors accelerate or decelerate entry into the postparental phase. We employed the semi-parametric model of the Cox regression, thus an event history method, which the literature often calls a proportional hazards model (Blossfeld 2010). This offers the advantage that it can be used even if not all respondents experienced the move of the last child during the observation period. In addition, it is particularly suitable for analyses that do not have assumptions about the course of the baseline function (Weick 1993: 97), which is the case here for the entry into the postparental phase. The time spans examined begin at the age of 30 and end with the event of moving out of the parental home of the last child, or, in right-censored cases, with the age at the survey.

The rate of the move of the last child forms the dependent variable in the event history regression. This is the probability that parents who still live in a household with their children at a specific time will enter the postparental phase. The entry rate $r(t)$ is shown with a transition rate function $h_{0}(t)$ that is the same for all subjects and the covariate influences $\exp ($.) that are multiplicatively and exponentially associated with it (Diekmann/Mitter 1993):

$$
r(t)=h_{o}(t) \cdot \exp \mathbb{\llbracket}\left(\beta_{1} x_{1}+\beta_{2} x_{2}+\cdots \rrbracket \beta_{m} x_{m}\right)
$$


The partial likelihood method (Blossfeld 2010: 1005) is used to estimate the Cox model. The effects of the covariates on the risk of entry are especially interesting for the event history regression. They can be read in the $\beta$ coefficients, whereby the antilogarithms of the $\beta$ coefficients $\left(\alpha_{i}=\exp \beta_{i}\right)$ are easier to interpret because they can be understood as percent effects $\left(\alpha_{\mathrm{i}}-1\right) \cdot 100$ of the covariates on the risk of entry (Berger 2009; Ziegler/Schladt 1993).

\subsection{Data: Cox regression covariates}

Based on previous research findings (cf. Section 2), we included the following independent variables into the analyses using the KGP data. In addition, we include additional factors that were also identified as possible influencing variables.

Individual biography of the parents (respondents): The marriage age (in years), the age at the birth of the first child (in years) and the number of children are assumed to have important influences. For all three of these variables we expect that the lower they are, the earlier the entry into the postparental phase occurs. Additionally, the time between births can be included as a further explanatory variable, because the greater the time between the first and the last child, the later entry will be. These are included in years as the difference between the times of the first and the last birth. In addition, we examined how the age of the parents on their own leaving of the parental home (in years) affects the probability of entry into the postparental phase. An early own departure by the parents can have a positive influence on the time of their children's departure because it can be considered a successful launch into independence, or a negative influence because it is associated more with stress and uncertainties, experiences that the parents transfer to their own children.

Educational and occupational history of the parents (respondents): The educational level is measured by the attaining of a university entrance diploma and an academic degree. The school and academic degrees of the partners could be constructed since the KGP also asks about their educational history. Mothers and fathers are differentiated, so that separate variables are created for the mothers and fathers with a university entrance diploma and academic degrees. We assume that a higher degree delays the entry into the postparental phase. The vocational training is also included. Determining the influence of vocational training is more difficult because parents who completed vocational training can either imagine a higher educational degree for their children or be satisfied with one of equal status and refuse to finance their children's academic studies. Since the employment status of the mother proved significant in previous research findings, we created the time dependent variable "Employment status of the mother at the time of the move of the child."

The income chosen was the monthly household income, which is calculated from the highest achieved income in the phase between the age of 43 and 56 years and the current income of the partner. Using the highest achieved income rather than the average income can provide more variance. We needed to determine in which way income affects the entry into the postparental phase. Since the KGP does 
not ask about housing we are unable to distinctly differentiate whether the income refers to household-specific resources or rather indicates the possibility of transferable resources.

The biography of the child of the respondent's child cannot be integrated as easily as that of the parents. The fact that the respondents have more than one child can lead to significant effects mutually eliminating one another, for example if someone has one son and one daughter, including the gender alone cannot exhibit distinct effects if daughters, for example, leave home earlier and sons later. Therefore, the variables for the children were based on the last child who moved out or on the youngest child still remaining in the household. In addition, no times were surveyed in the children's biographies, thus no conclusions can be made about the chronological correlation from entry into the postparental phase and employment, for example. We use five dummy variables: university entrance diploma (yes/ no), academic degree (yes/no), vocational training completed (yes/no), employment (yes/no), gender (male/female). Only those children 18 years and older are included in the analyses, since the KGP only asks the parents whether their children over 18 years old have their own household.

The model in Figure 1 shows the influencing variables mentioned above and their assumed effect on the entry into the postparental phase, by parents' and children's characteristics.

Fig. 1: $\quad$ Covariate effects on the risk of entry into the postparental phase according to characteristics of the parents and children and assumed effects

\section{Parents}

Child

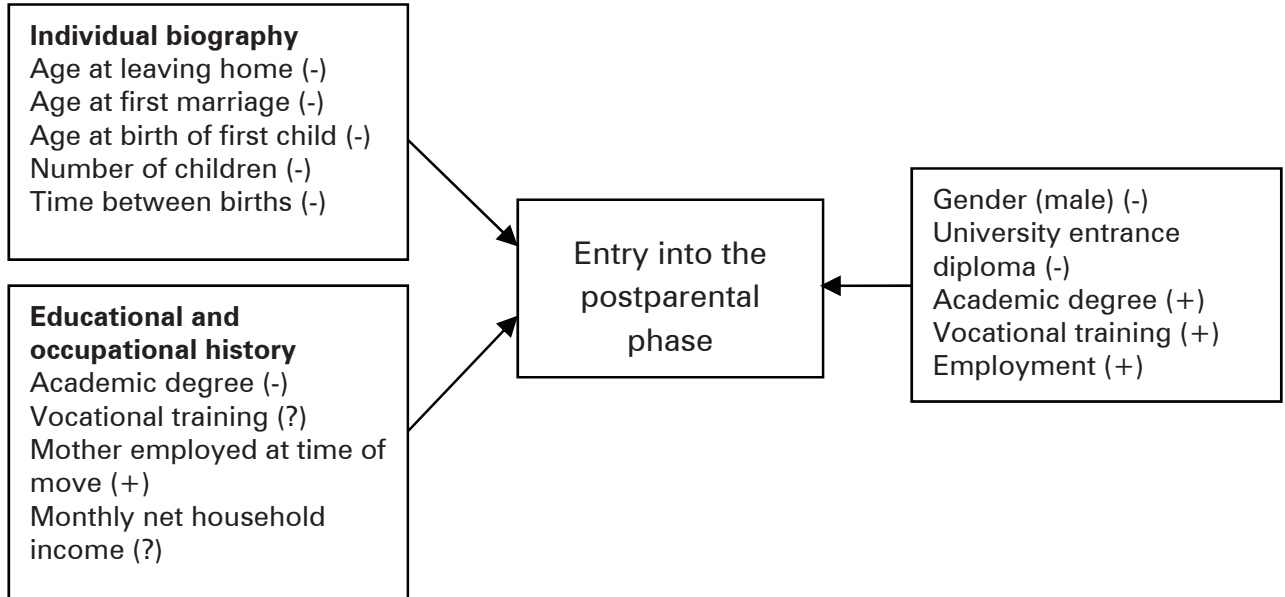

Source: Own design 
Tab. 1: Summary of the independent variables: range, mean values and standard deviations for parents and children over 18 years of age $(\mathrm{N}=530)$

\begin{tabular}{lccr}
\hline Variable & Range & Mean value & SD \\
\hline Age at entry into postparental phase & $43-59$ & 54.6 & 2.81 \\
Parents (respondents) & & & \\
Age at first marriage & $18.9-39.3$ & 27.5 & 3.95 \\
Birth of first child & $20-42.5$ & 30.3 & 3.91 \\
Age at own leaving home & $17.7-36.1$ & 23.3 & 3.24 \\
Number of children & $1-5$ & 2.2 & 0.85 \\
Time between births in years & $0-13.7$ & 3.8 & 3.04 \\
Vocational training respondent & $0 / 1$ & .39 & - \\
Academic studies father & $0 / 1$ & .69 & - \\
Academic studies mother & $0 / 1$ & .53 & - \\
University entrance diploma father & $0 / 1$ & .78 & - \\
University entrance diploma mother & $0 / 1$ & .65 & - \\
Monthly net household income & $400-129294$ & 6282.50 & 8102.1 \\
Mother employed at time of move (time & & & \\
dependent) & $0 / 1$ & .73 & - \\
Children & & & \\
Gender (male) & $0 / 1$ & .51 & - \\
University entrance diploma & $0 / 1$ & .67 & - \\
Vocational training & $0 / 1$ & .25 & - \\
Academic studies & $0 / 1$ & .58 & - \\
Employment & $0 / 1$ & .29 & - \\
Age & $18.1-36.9$ & 22.20 & 3.27 \\
\hline
\end{tabular}

1 This share only refers to the women in the sample. For the entire sample, the number of employed mothers is 33 percent.

Source: Own calculations

Table 1 summarises the cited variables including the range of values and mean values. They are listed here only briefly to present the sample and in order to achieve a better understanding of the effects of these variables in the Cox regression.

The KGP respondents show educational levels above the average.69 percent of the fathers hold an academic degree and 53 percent of the mothers, while only an average of 17 percent of the respective age group of 50 to 59-year-olds in the general population are university graduates (Datenreport 2011). The percentage of parents with university entrance diploma, at 78 percent among the fathers and 65 percent among the mothers, is also very high compared to only 24 percent in the general population of the same age group. By contrast, a lower number of the former grammar school pupils went through vocational training, compared to the 
reference group of the total population (58 percent). The net household income exhibits broad variance with the average lying above 6,000 euros. 73 percent of the mothers were working at the time the last child left home.

Like the parents, a large number of the children also have a university entrance diploma (67 percent), while only 25 percent completed vocational training. But 58 percent already hold academic degrees and 29 percent are working full time.

Before including the independent variables into the Cox regression, we first had to identify possible correlations between the individual factors and eliminate them in order to exclude possible multicollinearities. In particular, we assume that the demographic variables mutually influence each other, because those who marry early will most probably also have children at an earlier age than those who marry late. If variables correlate too highly with one another $(r>0.3)$ one will be excluded from the analyses. The results of the correlations are not shown here, but the most important findings that are of significance for the further analysis are mentioned briefly: the age at first marriage correlates very highly with the age at the birth of the first child, we anticipate, however, that the age at birth is more closely correlated to the move of the children than the age at marriage. The number of children and the time between births correlate very highly, but since the number of children is asked more often in other surveys than the complete individual biography, we include this variable. The educational variables also correlate very highly with one another, which is why only the academic degree is used as an independent variable for mothers, fathers and children, since the numbers of those without academic degrees are higher than those without a university entrance diploma.

\section{Chronological positioning of the transition into the postparental phase within the life course}

When can parents expect to live again as a couple within their own home? We plotted this question using the "survival rate" for parents with children in the household. 254 (42 percent) of the 605 people, are currently in the postparental phase and thus have no children living in the household; at least one child is living in the household of 351 (58 percent) people. Lauterbach (2004) dates the time of entry into the postparental phase at the sixth decade of life (Lauterbach 2004: 162). Mayer and Wagner (1989) calculate the median age of fathers in the cohort 1949-51 at 56 years if they have sons and 52 years if only daughters are considered. For mothers of the same cohort, the median is 53 years for sons and 49 years for daughters. In the cohort studied here, the differences between parents with daughters and sons are less extreme, with the median age of fathers at 57 years for daughters and 58 years for sons and of mothers at 55 years for daughters and 57 years for sons. ${ }^{2}$ Looking at different cohorts, Lauterbach (2004: 166-175) states that since the post-war era, fa-

2 Since not all parents experienced the move of the last child, the median age was estimated using the life table method. 
thers and mothers enter the late family phase ever earlier and the numbers of those who experience this phase at all has risen.

The chronological difference between men and women at the entry into the postparental phase cannot only be determined through the median, but also using survival curves for men and women (Fig. 2). The two curves differ significantly (Wilcoxon: $17.78 \mathrm{p}=.000$; log rank: $15.16 \mathrm{p}=.000$ ). Thus, women experience entry into the postparental phase earlier than men. At the age of 56 years, 53 percent of the mothers are faced with a childless household, but only 38 percent of the fathers. Both survival curves run parallel to one another with men lagging behind the women about three years. This distance quite precisely corresponds to the earlier entry of the women into the family life cycle calculated for this cohort: the average age at first marriage is 29 years for men and 26 for women.

Fig. 2: "Survival rate" of mothers and fathers in households with children

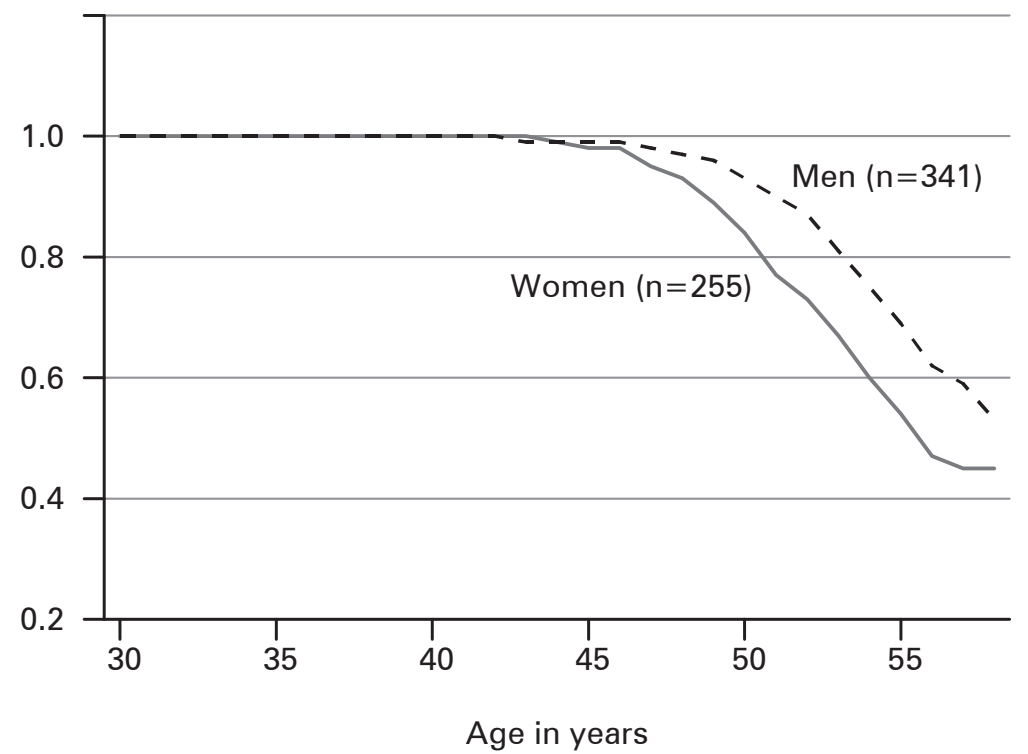

Source: Own calculations and design

The survival curve also reveals that the move of the last child can be anticipated for women at the earliest at about the age of 45 and for men at 48 years and afterwards the share rises gradually. For half of the parents the transition occurs between the ages of 45 and 55 (mothers) and 48 and 58 (fathers). This means that the majority of these parents already live in a childless household before their retirement. Since the KGP is an educationally selective subpopulation, it is reasonable to assume that the survival rate among the total population already decreases at an earlier age. 


\section{$5 \quad$ Entry into the postparental phase}

The chronological positioning of the entry into the postparental phase shown above reveals quite well when parents can expect their last child to leave home. In this section, we now include the variables named in Section 3.3 into the Cox regression as possible influences on the probability of entry into the postparental phase. The results are shown in Table 2. A variety of models were calculated, in which the influences of the individual biographies, occupational histories and the children's characteristics were calculated separately as well as in a total model.

The individual biography of the parents has a very strong influence on the risk of entry into the postparental family phase, as seen in Model 1. The age at the first birth lowers the risk of entry significantly by 19 percent, a value resulting by subtracting the a coefficients (.81) from the value 1. It means that per additional year of age at the birth of the first child, the hazard rate drops by 19 percent, thus slowing down entry into the postparental phase. The number of children also has a very strong influence: the risk of entry into the postparental phase drops by 61 percent per additional child. The own age at leaving home also decelerates entry: the older the respondents were on their own move, the later they enter the postparental phase. Since this variable has a significant effect at the 5-percent level, also when controlling for age at the birth of the first child, it appears that one's own departure possesses an independent effect. Since the age upon leaving home correlates with the educational history (Section 3.3), we assume that it loses significance when we also control for the parents' educational history. The strong influence of the individual biography on the risk of entry into the postparental phase is, however, not really surprising. The effects of the other covariates when controlling for the individual biography are more interesting.

Model 2 includes the individual biography as well as the educational and occupational history of the parents. On the one hand, it reveals that the strong influences of the age at the birth of the first child and the number of children remain or even slightly increase, on the other hand that the age on one's own departure still has a significant effect when controlling for the educational history. This implies that the children of parents who left home late themselves also remain in the parental home longer. As for the educational and occupational history, we see that neither the father's academic degree, nor parents who were in vocational training or are still working at the departure of the children, particularly mothers, have an effect on the speed of entry into the postparental phase. Hence, it makes no difference in the children's decision to move out whether the mother is employed the time of their move or not. However, mothers with an academic degree enter the phase earlier than mothers without academic degrees regardless of the number of children and their age at the birth of the first child. This increases the rate by 36 percent. Although academic studies usually lead to a higher age at the birth of the first child, this apparently also leads to an earlier entry into the postparental phase. The fact that the mother's academic degree has a stronger effect on the timing of leaving home than that of the father may be because mothers, through their closer contact with their children, influence them more in their educational careers and are more 


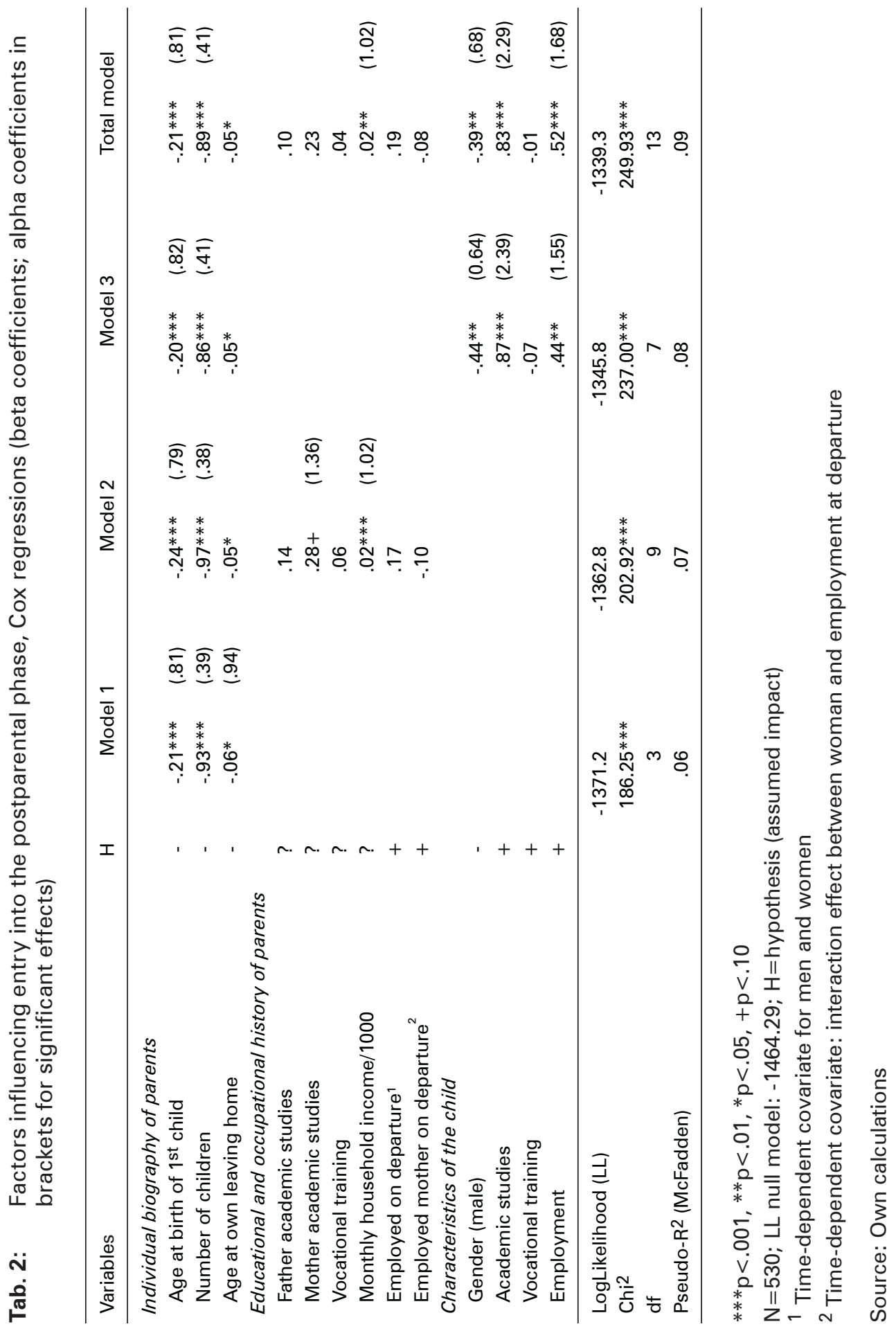


likely to be able to persuade them to pursue academic studies, which usually causes a move. The monthly household income (divided by 1,000 ) also has a positive and significant effect. Thus a high income promotes the move of own children since these parents can assumedly offer their children the opportunity of establishing their own household. All in all, we can say that although the educational and vocational history clearly influence the events of starting a family (Birkelbach 1998), it apparently loses significance for the ensuing phases of the family life cycle.

The characteristics of the children were included in the analyses in Model 3. These findings should, however, be interpreted with some caution for, as mentioned above, these are not time dependent variables. For example, we cannot trace a causal correlation from entry into working life and the time of leaving home. Since the data of the last child to move out compared to the youngest child still living at home serve as the basis, the results of Model 3 can be interpreted as follows: If the last child living at home is a son, the risk of entry into the postparental phase drops by 36 percent. If this child has an academic degree, this favours the entry into the postparental phase by 139 percent. If the child is employed, the risk of entry increases by 55 percent. By contrast, vocational training has no significant effect. These results correspond to previous studies examining the home-leaving behaviour of men and women (e.g. Ziegler/Schladt 1993; Berger 2009; Lauterbach 2004).

The total model estimates the influences of the individual variables while controlling for and stabilising the other covariates. The influence of the individual biography remains strong, but with regard to the educational and occupational history the mother's academic degree loses significance but only little of its effect when controlled for the children's characteristics. Household income retains its weak positive influence. The effects of the children's characteristics change only slightly, for instance the child's academic studies increase the rate by 129 percent and employment by 68 percent and sons decelerate the transition by 32 percent. The characteristics of the children apparently have a stronger effect on the probability of entry into the postparental phase than that of the parents. Only the income continues to have a weak positive effect on the entry.

By comparing the log-likelihood values and the related pseudo $\mathrm{R}^{2}$, it becomes clear that the inclusion of the educational and vocational variables does not improve the model. But the model does become better by including the children's characteristics, although the total model does not show any improving effects. Apparently, the information from the individual biography and the children's characteristics are sufficient for analysing the risk of entry into the postparental phase.

\section{Summary and conclusions}

The majority of parents experience the move of their last child during the sixth decade of life. However, the analyses show that for those who moved out of their own parental household early, entry into the postparental phase also occurs earlier than for those who moved out later. As expected, the age at the birth of the first child has an even greater influence on the time of entry: the younger the parents are, 
the earlier they can expect their children to leave home. The number of children is equally significant. If it is low, the parents will live alone in their household earlier. This confirms that entry into the postparental phase is strongly dependent on decisions made early within the life course.

The occupational history of parents has no importance for their entry into the postparental phase. Neither an academic degree, nor vocational training nor employment of the mother at the time of departure can be identified as distinct factors. Solely a higher income favours the entry and thus the move of the last child. The child's vocational and educational history is far more significant. When children begin studies or work the parents can expect their children to leave home much earlier. The gender of the child is just as important: sons stay at home longer than daughters.

The longitudinal analysis clearly reveals that the parent's lives and the characteristics of the children are significant for the entry into the postparental phase.

Not all of the determinants mentioned at the start were included in the analyses since some of them correlated very strongly with one another and this effect would have been reflected in the regression model. However, for further analyses we can say that the correlating variables are interchangeable since they have the same effect.

Finallly, we would also like to mention some limitations of this study. The results are based on an educationally selective sample and cannot be transferred to the total population. In addition, some restrictions were made from the outset concerning the family histories: only those respondents with normal family histories - no divorced or widowed people - were included in the analyses. Influences by such events would have to be accurately included into the theoretical model and empirically proven. Moreover, this is only one birth cohort. It would be interesting to learn whether influences shown here also prove to be significant among other cohorts.

In further analyses of the transition into the postparental phase, it would be interesting to look at the quality of relationships between parents and children prior to their moving out, an aspect that was not surveyed in the KGP. In addition, the housing situation of families and the respective standard of living could provide additional findings about the risk of entry. Future research should examine more precisely how the entry itself affects the lives of the parents, for example, it may be that the move of the last child affects the significance of the family by lowering their status. Or perhaps no longer needing to care for children could affect the parents' vocational lives, in particular that of mothers, since they then have more time available for employment. Similarly, entry into the postparental phase could have an impact on other spheres of life such as the use of leisure time.

\section{References}

Bart, Pauline B. 1971: Depression in middle-aged women. In: Gornick, Vivian; Moran, Barbara K. (Eds.): Woman in sexist society. Studies in power and powerlessness. New York: Basic Books: 99-117. 
Berger, Fred 2009: Auszug aus dem Elternhaus - Strukturelle, familiale und persönlichkeitsbezogene Bedingungsfaktoren. In: Fend, Helmut (Ed.): Lebensverläufe, Lebensbewältigung, Lebensglück. Ergebnisse der LifE-Studie. Wiesbaden: VS Verlag für Sozialwissenschaften: 195-243.

Birkelbach, Klaus W. 1998: Berufserfolg und Familiengründung. Lebensläufe zwischen institutionellen Bedingungen und individueller Konstruktion. Opladen: Westdeutscher Verlag.

Birkelbach, Klaus W. 2011: Ausfälle im Kölner Gymnasiastenpanel 1969 - 2010: Ursachen und mögliche Folgen für die Datenqualität. In: Birkelbach, Klaus W. et al. (Eds.): Vor dem Lebensabend - eine dritte Wiederbefragung zu Lebenserfolg und Erfolgsdeutung ehemaliger 16-jähriger Gymnasiasten im 56. Lebensjahr: Erste Analysen. Unveröffentlichter Zwischenbericht zur Vorlage bei der Deutschen Forschungsgemeinschaft. Köln/Essen: 1-30.

Blossfeld, Hans; Golsch, Katrin; Rohwer, Götz 2007: Event History Analysis with Stata. Mahwah (NJ): Erlbaum.

Blossfeld, Hans 2010: Survival- und Ereignisanalyse. In: Wolf, Christof; Best, Henning (Eds.): Handbuch sozialwissenschaftliche Datenanalyse. Wiesbaden: VS Verlag für Sozialwissenschaften: 995-1016.

Cox, David R. 1972: Regression Models and Life-Tables. In: Journal of the Royal Statistical Society. Series B, 34: 187-220.

Datenreport 2011: Ein Sozialbericht für die Bundesrepublik Deutschland (2011). Bonn: $\mathrm{BpB}$, Bundeszentrale für politische Bildung.

Dennerstein, Lorraine; Dudley, Emma; Guthrie, Janet 2002: Empty nest or revolving door? A prospective study of women's quality of life in midlife during the phase of children leaving and re-entering the home. In: Psychological Medicine 32: 545-550 [doi: 10.1017/S0033291701004810].

Deykin, Eva; Jacobson, Shirley; Klerman, Gerald; Solomon, Maida 1966: The empty nest: Psychosocial aspects of conflict between depressed women and their grown children. In: American Journal of Psychiatry 122: 1422-1426.

Diekmann, Andreas; Mitter, Peter 1984: Methoden zur Analyse von Zeitverläufen: Anwendungen stochastischer Prozesse bei der Untersuchung von Ereignisdaten. Stuttgart: Teubner.

Diekmann, Andreas; Mitter, Peter 1993: Methoden der Ereignisanalyse in der Bevölkerungssoziologie: Stand und Probleme. In: Diekmann, Andreas; Weick, Stefan (Eds.): Der Familienzyklus als sozialer Prozess. Bevölkerungssoziologische Untersuchungen mit den Methoden der Ereignisanalyse. Berlin: Duncker \& Humblot: 20-65.

Feser, Herbert; Müller-Daehn, Sigrid; Schmitz, Uta 1989: Familienfrauen im mittleren Alter. Lebenssituation und Zukunftsperspektiven. Stuttgart: W. Kohlhammer.

Filipp, Sigrun-Heide (Ed.) 1990: Kritische Lebensereignisse. 2., erw. Auflage München: Psychologie Verlags Union.

Glick, Paul C. 1955: The Life Cycle of the Family. In: Marriage and Family Living 17,1: 3-9 [http://www.jstor.org/stable/346771, 27.01.2015].

Höhn, Charlotte 1982: Der Familienzyklus. Zur Notwendigkeit einer Konzepterweiterung. Boppard am Rhein: Boldt.

Lauterbach, Wolfgang 2004: Die multilokale Mehrgenerationenfamilie. Zum Wandel der Familienstruktur in der zweiten Lebenshälfte. Würzburg: Ergon. 
Mayer, Karl-Ulrich; Wagner, Michael 1989: Wann verlassen Kinder das Elternhaus? In: Strohmeier, Alois; Herlth, Klaus P. (Ed.): Lebenslauf und Familienentwicklung. Mikroanalysen des Wandels familialer Lebensformen. Opladen: Leske \& Budrich: 7-37.

Meulemann, Heiner 1995: Die Geschichte einer Jugend. Lebenserfolg und Erfolgsdeutung ehemaliger Gymnasiasten zwischen dem 15. und 30. Lebensjahr. Opladen: Westdeutscher Verlag.

Mitchell, Barbara A. 1994: Family Structure and Leaving the Nest: A Social Resource Perspective. In: Sociological Perspectives 37,4: 651-671.

Nave-Herz, Rosemarie 2002: Wandel und Kontinuität in der Bedeutung, in der Struktur und Stabilität von Ehe und Familie in Deutschland. In: Nave-Herz, Rosemarie (Ed.): Kontinuität und Wandel der Familie in Deutschland. Eine zeitgeschichtliche Analyse. Stuttgart: Lucius und Lucius: 45-70.

Papastefanou, Christiane 1997: Auszug aus dem Elternhaus: Aufbruch und Ablösung im Erleben von Eltern und Kindern. Weinheim: Juventa Verlag.

Papastefanou, Christiane 2000: Der Auszug aus dem Elternhaus - ein vernachlässigter Gegenstand der Entwicklungspsychologie. In: Zeitschrift für Soziologie der Erziehung und Sozialisation 20,1: 55-69.

Pinquart, Martin; Silbereisen, Rainer K. 2007: Familienentwicklung. In: Brandstädter, Jochen; Lindenberger, Ulman (Eds.): Entwicklungspsychologie der Lebensspanne. Ein Lehrbuch. Stuttgart: Kohlhammer: 483-509.

Radloff, Lenore Sawyer 1980: Depression and the Empty Nest. In: Sex Roles 6,6: 775-781.

Scherger, Simone 2007: Destandardisierung, Differenzierung, Individualisierung. Westdeutsche Lebensläufe im Wandel. 1. Aufl. Wiesbaden: VS Verlag für Sozialwissenschaften.

Scherger, Simone 2009: Social change and the timing of family transitions in west germany. Evidence from cohort comparison. In: Time and Society 18,1: 106-129 [doi: 10.1177/0961463X08099947].

Szydlik, Marc; Schupp, Jürgen 1998: Stabilität und Wandel von Generationenbeziehungen. In: Zeitschrift für Soziologie 27,4: 297-315.

Wagner, Michae/ 1989: Räumliche Mobilität im Lebensverlauf: eine empirische Untersuchung sozialer Bedingungen der Migration. Stuttgart: Enke Verlag.

Wawrzyniak, Barbara 2014: Die subjektive Bedeutung der Familie in der nachelterlichen Phase. Phil. Diss. Essen-Duisburg.

Weick, Stefan 1993: Determinanten des Auszugs aus der elterlichen Wohnung. In: Dieckmann, Andreas; Weick, Stefan (Eds.): Der Familienzyklus als sozialer Prozeß - Bevölkerungssoziologische Untersuchung mit den Methoden der Ereignisanalyse. Berlin: Duncker und Humblot: 86-108.

Ziegler, Rolf; Schladt, Diana 1993: Auszug aus dem Elternhaus und Hausstandsgründung. In: Diekmann, Andreas; Weick, Stefan (Eds.): Der Familienzyklus als sozialer Prozess. Bevölkerungssoziologische Untersuchungen mit den Methoden der Ereignisanalyse. Berlin: Duncker \& Humblot. 
Translated from the original text by the Federal Institute for Population Research, for information only. The reviewed and author's authorised original article in German is available under the title "Der Eintritt in die nachelterliche Familienphase", DOI 10.12765/CPoS-2015-01de or URN urn:nbn:de:bib-cpos-2015-01de8, at http://www.comparativepopulationstudies.de.

Date of submission: 25.10 .2012

Date of acceptance: 10.01 .2014

Dr. Barbara Wawrzyniak ( $₫)$. Universität zu Köln, Institut für Soziologie und Sozialpsychologie (ISS). Köln. Germany. E-Mail: barbara.wawrzyniak@gmx.net URL: http://www.iss-wiso.uni-koeln.de/wawrzyniak.html?\&L=0 


\section{Comparative Population Studies}

WWW.comparativepopulationstudies.de

ISSN: 1869-8980 (Print) - 1869-8999 (Internet)

Published by / Herausgegeben von

Prof. Dr. Norbert F. Schneider

Federal Institute for Population Research

D-65180 Wiesbaden / Germany

\section{Managing Editor /}

Verantwortlicher Redakteur

Frank Swiaczny

\section{Assistant Managing Editor /}

\section{Stellvertretende Redakteurin}

Katrin Schiefer

\section{Copy Editor (German) /}

Lektorat (deutsch)

Dr. Evelyn Grünheid

\section{Layout / Satz}

Beatriz Feiler-Fuchs

E-mail:cpos@bib.bund.de

\section{Scientific Advisory Board /}

Wissenschaftlicher Beirat

Paul Gans (Mannheim)

Johannes Huinink (Bremen)

Michaela Kreyenfeld (Rostock)

Marc Luy (Wien)

Clara H. Mulder (Groningen)

Notburga Ott (Bochum)

Peter Preisendörfer (Mainz)

Zsolt Spéder (Budapest)
Board of Reviewers / Gutachterbeirat Martin Abraham (Erlangen)

Laura Bernardi (Lausanne)

Hansjörg Bucher (Bonn)

Claudia Diehl (Konstanz)

Andreas Diekmann (Zürich)

Gabriele Doblhammer-Reiter (Rostock)

Jürgen Dorbritz (Wiesbaden)

Anette Eva Fasang (Berlin)

E.-Jürgen Flöthmann (Bielefeld)

Alexia Fürnkranz-Prskawetz (Wien)

Beat Fux (Salzburg)

Joshua Goldstein (Berkeley)

Karsten Hank (Köln)

Sonja Haug (Regensburg)

Hill Kulu (Liverpool)

Aart C. Liefbroer (Den Haag)

Kurt Lüscher (Konstanz)

Emma Lundholm (Umeå)

Nadja Milewski (Rostock)

Dimiter Philipov (Wien)

Roland Rau (Rostock)

Tomáš Sobotka (Wien)

Jeroen Spijker (Barcelona)

Olivier Thévenon (Paris)

Helga de Valk (Brussel)

Heike Trappe (Rostock)

Michael Wagner (Köln) 